\title{
Transgenic mice expressing small interfering RNA against Gata4 point to a crucial role of Gata4 in the heart and gonads
}

\author{
Boris Thurisch, Shermi Y Liang1, Nanette Sarioglu², Lutz Schomburg ${ }^{3}$, Jörg Bungert ${ }^{1 *}$ \\ and Christof Dame* \\ Department of Neonatology, Charité-Universitätsmedizin Berlin, Campus Virchow-Klinikum, Augustenburger Platz 1, D-13353 Berlin, Germany \\ ${ }^{1}$ Department of Biochemistry and Molecular Biology, University of Florida, Gainesville, Florida 32610, USA \\ ${ }^{2}$ Institute of Pathology, Charité-Universitätsmedizin Berlin, D-10117 Berlin, Germany \\ ${ }^{3}$ Institute for Experimental Endocrinology, Charité-Universitätsmedizin Berlin, D-13353 Berlin, Germany \\ (Correspondence should be addressed to C Dame; Email: christof.dame@ charite.de) \\ *(C Dame and J Bungert designed the research work and contributed equally to this work)
}

\begin{abstract}
Homozygous deficiency of the transcription factor Gata4 in mice causes lethality due to defects in ventral morphogenesis and heart tube formation. There is increasing evidence demonstrating that GATA4 function is also relevant for normal developed organ systems, including the heart and endocrinum. To analyze the implication of Gata4 beyond development, we generated transgenic mice expressing inducible small interfering RNA against Gata4. In longitudinal analysis, efficient suppression of Gata4 mRNA (down to $80 \%$ of wild-type levels) and protein expression in the heart was detected 38 days after induction of Gata4 short hairpin RNA. Decreased Gata4 expression was associated with reduction in the expression of known cardiac target genes, but the function of the heart remained unperturbed at $20-30 \%$ of normal Gata4 levels. Interestingly, Gata4 expression was almost abolished in the ovary and testis. This was accompanied in the testis by a significant reduction of GATA4 downstream target genes, such as the genes encoding Mullerian inhibiting substance (MIS) and steroidogenic acute regulatory (StAR) protein. By contrast, expression levels of Mis and Star were only slightly modified in the ovary, and concentrations of circulating FSH and LH were normal in female transgenic mice after induction of Gata4 short hairpin RNA. However, inhibition of Gata4 expression led to the formation of ovarian teratoma in $10 \%$ of females. Histology of the teratomas showed predominantly ectodermal and mesodermal structures. Our data demonstrate that Gata4 is critically involved in the function and integrity of the gonads in vivo.
\end{abstract}

Journal of Molecular Endocrinology (2009) 43, 157-169

\section{Introduction}

The transcription factor GATA4 belongs to a family of six highly conserved zinc finger proteins, which bind to regulatory DNA fragments containing a 'T/A GATA G/A' core sequence. GATA factors are critically involved in the development and function of various organs (for review (Lowry \& Atchley 2000, Molkentin 2000)). Based on the phenotypes of Gata-deficient transgenic mice and subsequent analysis of downstream target genes, GATA4/5/6 were subgrouped as primary endodermal transcription factors (Molkentin 2000). Each factor exhibits a distinct developmental-stage and tissue-specific expression pattern. Cumulative data show that GATA4 is a critical regulator of cardiac gene expression, modulating cardiomyocyte differentiation and adaptive responses of the adult heart. GATA4 is also expressed in various endocrine organs. In the male and female gonads, GATA4 contributes to transcription of multiple hormone-encoding genes (Viger et al. 2008).

In mice, homozygous Gata4 deficiency $\left(\right.$ Gata $\left.^{-/-}\right)$ results in embryonic lethality between 8.5 and $10.5 \mathrm{dpc}$ due to defects in yolk sac vasculogenesis, ventral morphogenesis, and heart tube formation (Kuo et al. 1997, Molkentin et al. 1997). Mutant mice with cardiacspecific deletion of Gata4 show hypoplasia of the right ventricle during embryonic development; at later stages this heart fails to react by hypertrophy in consequence of hypertension and shows reduced myocyte viability (Zeisberg et al. 2005, Oka et al. 2006). However, transgenic mice with heterozygous Gata4 deficiency $\left(\right.$ Gata4 $\left.^{+/-}\right)$do not suffer from cardiac failure (Kuo et al. 1997, $\mathrm{Pu}$ et al. 2004). Other data from transgenic mice indicate that a critical Gata4 expression level is required for normal cardiac development and function (Pu et al. 2004, Zeisberg et al. 2005, Bisping et al. 2006, Oka et al. 2006, Jay et al. 2007, Rajagopal et al. 2007).

DOI: 10.1677/JME-09-0030 Online version via http://www.endocrinology-journals.org 
Transgenic models that overcome early embryonic lethality associated with Gata4 deficiency provided the first evidence for GATA4 function in endocrine organs. Mice homozygous for a Gata4 variant $\left({G a t a 4^{k i / k i}}^{k}\right)$ that cannot interact with its cofactor friend-of-GATA2 (FOG2) show abnormal morphology of the testis (Tevosian et al. 2002, Manuylov et al. 2007). Recently, chimeric mice, generated by injection of Gata4 ${ }^{-1-}$ embryonic stem (ES) cells into Rosa26 blastocytes, have shown that GATA4 is directly required for the differentiation of Leydig cells in the fetal murine testis (Bielinska et al. 2007). Although various putative GATA4 target genes have been identified in the testis and ovary by means of in vitro studies (for review see (Viger et al. 2008)), to our knowledge no in vivo genetic model is currently available that elucidates GATA4 function in the ovary.

The in vivo function of GATA4 in the heart and endocrine organs is of increasing interest, since GATA4 haploinsufficiency has been identified in humans (Pehlivan et al. 1999, Garg et al. 2003). Although the number of patients suffering from GATA4 mutations reported in the literature are still relatively low, evidence is given that septal heart defects, in particular atrial septal defects of the secundum type and ventricular septal defects, as well as tetralogy of Fallot are predominant phenotypes (Pehlivan et al. 1999, Garg et al. 2003, Okubo et al. 2004, Hirayama-Yamada et al. 2005, Sarkozy et al. 2005, Nemer et al. 2006, Tang et al. 2006, Rajagopal et al. 2007, Tomita-Mitchell et al. 2007). Data on non-cardiac phenotypes in individuals with reduced GATA4 expression are very limited, but such disorders may include delayed psychomotor development (Pehlivan et al. 1999) or endocrine disorders. In mice, GATA4 deficiency can be induced by the chemotherapeutic agent doxorubicin ( $\mathrm{Li}$ et al. 2006). These findings underline that GATA4 is a clinically relevant transcription factor, and the question regarding dose- and/or time-dependent effects of reduced GATA4 expression becomes of increasing interest for clinical medicine (Rajagopal et al. 2007, Viger et al. 2008).

We generated a double-transgenic mouse expressing the tetracycline repressor ( $T e t R$ ) and an inducible small interfering RNA (siRNA) directed against Gata4 in order to achieve dose- and/or time-dependent suppression of Gata4 expression. In vivo RNA interference (RNAi) has recently been established, but the general experience with such mouse models is still limited (Hasuwa et al. 2002, Bantounas et al. 2004, Kühn et al. 2007, Seibler et al. 2007). Herein, we successfully generated a novel transgenic mouse line expressing inducible Gata4 siRNAs (siGata4) and analyzed the effects of in vivo GATA4 reduction on tissue-specific gene expression and organ function, in particular the heart and gonads.

\section{Material and Methods}

\section{Cell culture}

C2C12 myoblast cells (ATCC CRL-1772; Manassas, VA, USA) were grown in DMEM (Invitrogen) supplemented with $2 \mathrm{mM}$ glutamine, 10\% FCS (Biochrom, Berlin, Germany), and 5\% antibiotics (penicillin/ streptomycin; Biochrom).

\section{In vitro RNA interference}

The pTER + plasmid was used to express Gata4 siRNA in C2C12 cells (van de Wetering et al. 2003). After software-based exclusion of significant homology within the murine genome, oligonucleotides corresponding to the murine Gata4 coding sequence (NCBI accession no. NM_008092; construct 1: nt +1214 to +1234; 5'-GATCCCTCTCGATATGTTTGATGA CTTCAAGA GA GTCATCAAACATATCGAGATTTTTGGAAA- ${ }^{\prime}$; construct 2 : $\mathrm{nt}+1242$ to +1262 ; 5'-GATCCCGGCAGAGAGTGTGTCAATTTTCAAGAGAAATTGACACACTCTCTGCCTTTTTGG AAA-3' ${ }^{\prime}$; shScram: 5'-GATCCC GTTAACTTCTTAATTGTGG TTCAAGAGA CCACAATTAAGAAG TTAACTTTTTGGAAA- $3^{\prime}$, plus their corresponding $3^{\prime} \rightarrow 5^{\prime}$ sequences) were ligated and cloned into pTER+. Transfections were carried out using FuGENE 6 transfection reagent (Roche Diagnostics). Highest efficiency was reached using FuGENE 6 and DNA in a 3:1 ratio. Four hours after transfection FCS (final concentration of $10 \%$ ) and antibiotics (penicillin/streptomycin, final concentration of $5 \%$ ) were added.

\section{Generation of transgenic mice}

FvB mice were used to generate the transgenic H1:G4/TetR strain. The coding sequence for the mouse Gata4 short hairpin RNA (shRNA; construct 1) was ligated downstream of the $\mathrm{H} 1$ promoter using the plasmid pTER + (Fig. 1A). The H1 promoter contains an operator sequence (TO) for the tetracycline (Tet) repressor (TetR), which inactivates the promoter (Fig. 1B). Doxycycline antagonizes TetR function and induces expression mediated by the $\mathrm{H} 1$ promoter. Plasmid pcDNA6/TR (Invitrogen) was digested with XhoI and SaII; pTER:shGata4 was digested with ScaI and $S t u I$. Target plasmid fragments were purified from agarose gels and resuspended in injection buffer at a concentration of $2 \mathrm{ng} / \mu \mathrm{l}$ (Bungert et al. 1995). Transgenic mice were generated in the transgenic core facility of the University of Florida, where the study was approved by the Institutional Review Board (IRB protocol No. D669). Transgenic founders were 
A

Gene locus
mRNA
$(3.4 \mathrm{~kb})$
Coding sequence
$(1.3 \mathrm{~kb})$

$(1.3 \mathrm{~kb})$

SiRNA

(19 bp)

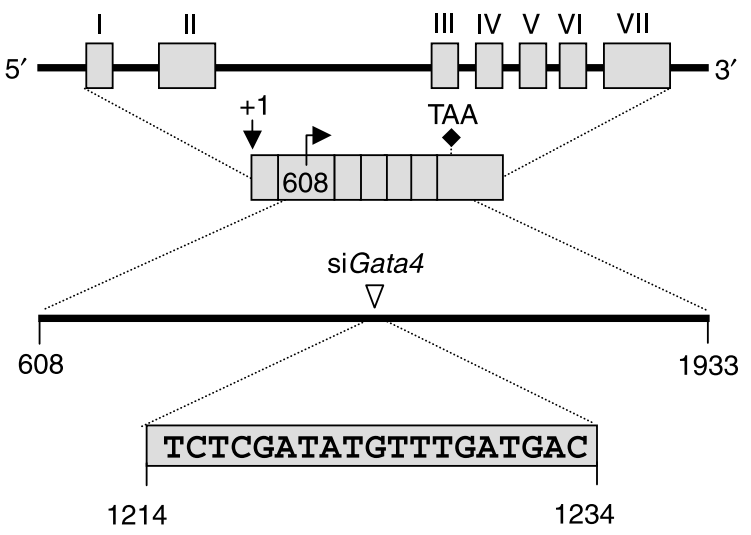

Spacer

TTCAAGAGA

GATCCC GG

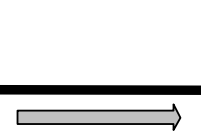

Sense
TTTTT, GGAAA

AAAAA CCTTTTCGA

\section{AAGTTCTCT}

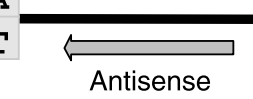

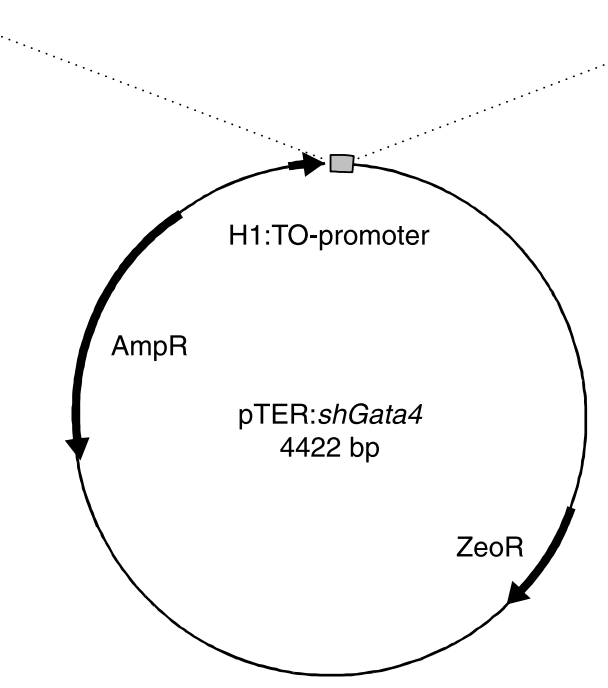

C

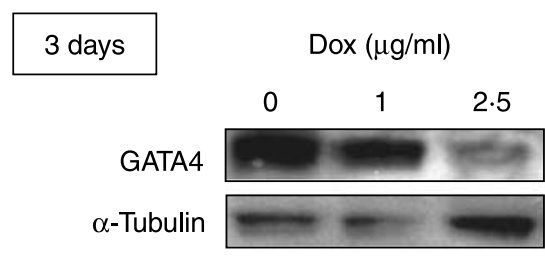

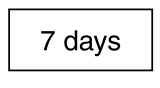

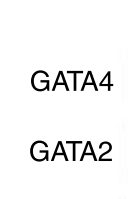

$\operatorname{Dox}(\mu \mathrm{g} / \mathrm{ml})$

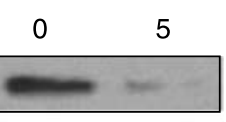

$\alpha$-Tubulin

Figure 1 Design and in vitro analysis of an inducible shRNA directed against murine Gata4. (A) Localization of the Gata4 siRNA sequence within the murine Gata4 gene locus (NCBI NT_039606), the Gata4 mRNA (transcription start nt +1; translation start nt 608; stop codon: TAA; NCBI NM_008092), and the coding mRNA (nt 608-1933). The sequence of the sense strand (nt 1214-1234) of the Gata4 siRNA is shown in the lower part of the panel. (B) Vector map of the pTER: shGata4 plasmid. Shown is the construct for the inducible doxycycline (Dox) regulated expression of short hairpin RNA (shRNA), initially described by van de Wetering et al. (2003). pTER: shGata4 contains a $\mathrm{H} 1$ promoter, recognized by RNA polymerase III, and a doxycycline-regulatory element upstream of the coding region for the Gata4 shRNA. TO, tetracycline operator; $\mathrm{H} 1$ :TO-promoter; $\mathrm{H} 1$ promoter modified by the tetracycline operator; $A m p R$, ampicillin resistance gene; ZeoR, zeocin resistance gene. (C) Analysis of in vitro efficiency of Gata4 shRNA. Murine C2C12 myoblasts were transfected with inducible Gata4 shRNA and TetR expression plasmids and incubated with doxycycline in a dose- and time-dependent manner. Expression of GATA4, GATA2, and $\alpha$-Tubulin was analyzed by western blot. 
identified by Southern blotting and confirmed by PCR. Double transgenic mice were mated to generate mice that carried both transgenes.

\section{DNA isolation, PCR screening and Southern blot analysis}

The presence of both transgenes was determined by Southern blot. Ten micrograms of genomic DNA was digested with HindIII, size fractionated on $1.2 \%$ agarose gels and transferred onto nylon membranes. Membranes were subsequently probed with DNA fragments corresponding to regions of the transgenes as previously described (Bungert et al. 1999). The H1:G4 probe is a $1143 \mathrm{bp} \mathrm{StuI-HindIII} \mathrm{fragment} \mathrm{derived}$ from pTER:shGata4 and corresponds to the H1:G4 transgene. The TetR probe is a $1591 \mathrm{bp}$ XhoI-HindIII fragment derived from pcDNA6/TR and corresponds to the TetR transgene. Transgene copy numbers were determined using the Phosphoimager system (Storage Phosphor Screen, Molecular Dynamics, Amersham Pharmacia Biotech) after hybridizing the nylon membranes for $14 \mathrm{~h}$ with a radioactive probe corresponding to the murine $\beta$-globin promoter ( $\mathrm{Li}$ et al. 1998). Radioactive signals were quantified using a PhosphoImager (Storm 860) and the IMAGEQUANT 5.0 software (both Amersham Pharmacia Biotech). For PCR, the following primers directed against DNA fragments of the transgenes were used: 1) H1:G4 transgene: sense $5^{\prime}$ GTCACTAGGCGGGAACACC- ${ }^{\prime}$, antisense $5^{\prime}$-ACGGG GGAGGGGCAAACAACAG-3' and 2) $T e t R$ transgene sense: $5^{\prime}$-TAGATAGGCACCATA CTCACTTTT-3', antisense: 5'-GGACCCACTTTCACATTT-3'.

\section{RT-PCR analysis of Gata4, Gata6, atrial natriuretic factor, bone morphogenic protein-4, $\alpha$-myosin heavy chain, oligoadenylate synthetase-2, Mullerian inhibiting substance, steroidogenic acute regulatory, and $\beta$-actin expression}

Total RNA was prepared as previously described (Dame et al. 2006). The RNA pellet was dissolved in diethyl pyrocarbonate-treated $\mathrm{H}_{2} \mathrm{O}$ at a concentration of $1 \mu \mathrm{g} / \mu \mathrm{l}$. First, strand cDNA synthesis was performed with $2 \mu \mathrm{g}$ total RNA using oligo(dT) primers and superscript II reverse transcriptase (Invitrogen; Dame et al. 2006). Expression analysis of the genes encoding atrial natriuretic factor (Anf; E et al. 2006), $\alpha$-myosin heavy chain $(\alpha-M h c$; E et al. 2006), Mullerian inhibiting substance (Mis; Wang et al. 2005), and steroidogenic acute regulatory protein (Star, Manna et al. 1999) was performed with primer sets as previously described. Expression analysis of the genes encoding Gata4, Gata6, bone morphogenic protein-4 (Bmp4), 2'-5'-oligoadenylate synthetase 2 (Oas2), $\beta$-actin, and Gapdh was performed with the following primer sets: Gata4: sense $5^{\prime}$-GATGGGACGGGACACTACCTG-3' ${ }^{\prime}$, antisense 5'- ACCTGCTGGCGTCTTAGA TTT-3'; Gata6: sense $5^{\prime}$-TTAACACTGATTGCTGCAACG- $3^{\prime}$, antisense $5^{\prime}$ GTT CATCGT AACGTGGCTGA-3'; Bmp4: sense 5'-ACCTC-

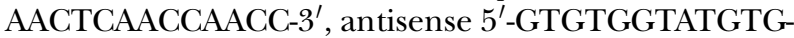
TAGGTGG-3'; Oas2: sense 5'-CAATAATGTGGGCAAAGATGATGG-3', antisense 5'-ACTGGGAGCGGTTGGTTTTTAGAG-3'; $\beta$-actin: sense $5^{\prime}$-ACTGCTCTGGCTCCTAGCAC-3 ${ }^{\prime}$, antisense $5^{\prime}$-ACATCTGCTGGAAGGTGGAC-3'; and Gapdh: sense 5'-CCAAGGTCATCCATGACAACT- $3^{\prime}$, antisense 5'ATCACGCCACAGCTTTCC-3' $^{\prime}$. PCR was carried out under the following conditions: DNA denaturation at $94{ }^{\circ} \mathrm{C}$; primer annealing at $60^{\circ} \mathrm{C}$ (except for Gata 4 : $62{ }^{\circ} \mathrm{C}$ ); and extension at $72^{\circ} \mathrm{C}(30$ cycles, except for Gata6: 27 cycles; 30 s each phase). cDNAs generated from the cell lines were amplified and PCR products were electrophoresed in $1.2 \%$ agarose gels and stained with ethidium bromide.

\section{RNA isolation and real-time PCR}

To induce the expression of siGata4, animals harboring the H1:G4 and tetR transgenes were fed with $20 \mathrm{mg}$ doxycycline $/ \mathrm{ml}$ drinking water (plus $2 \%$ sucrose). Animals were sacrificed at defined time points (after $14,29,38$, or 70 days respectively), and total RNA was extracted from heart, ovary, and testis, and reverse transcribed (Dame et al. 2006). One-twentieth of the reaction volume was used for quantification with the iCycler iQ Optical Real-Time PCR Detection System (Bio-Rad). The fluorescence threshold value was calculated using the iCycle iQ Optical System software 3.1. For Gata4 and $\beta$-actin, TaqMan Real-Time PCR was performed using commercially available primers (mGata4 Mm00484689_m1 and $\mathrm{m} \beta$-actin Mm00607939_s1; Applied Biosystems, Foster City, CA, USA). Mis and Star expression was analyzed by quantitative real-time PCR using the MiQ (Bio-Rad) using previously published primer sets (Wang et al. 2005, Rivera et al. 2009). Serial fivefold dilutions (100-0 $16 \mathrm{ng}$ ) of cDNA of wild type tissue were used for standard curve calculations. All real-time PCR reactions were performed in triplicate in a $20 \mu \mathrm{l}$ mixture containing $1 \mu \mathrm{l}$ cDNA, $10 \mu \mathrm{l}$ TaqMan, $2 \mu \mathrm{l}$ PCR Master Mix (Applied Biosystems), $1 \mu \mathrm{l}$ primer, and $8 \mu \mathrm{H}_{2} \mathrm{O}$. The transcript levels in the tissues of wild-type and transgenic mice were compared on the basis of standard curves.

\section{Western blot analysis}

Approximately, $20 \mu \mathrm{g}$ of whole protein extract from C2C12 myoblasts and $50 \mu \mathrm{g}$ of whole protein extract from tissue specimens respectively, were electrophoresed on $10 \%$ Ready Gels (Bio-Rad) under 
denaturing conditions. Transfer was performed using the Mini Protean apparatus (Bio-Rad). Incubation with antibodies (anti-GATA2 (H116), anti-GATA4 (C-20), antiGATA4 (H-112), anti- $\alpha$-Tubulin (TU-02), or anti- $\beta$-Actin (AC-15); all from Santa Cruz Biotechnology, Santa Cruz, CA, USA) and later detection of signals with appropriate HRP conjugated secondary antibodies were performed as previously described (Dame et al. 2004).

\section{Analysis of hormone concentrations}

Serum levels of LH and FSH were determined using a commercially available multiplex bead assay system (MILLIPLEX MAP rat pituitary panel, \#RPT86K) according to the manufacturer's instructions (Millipore, Amsterdam, The Netherlands). Briefly, serum samples and commercial controls were diluted 1:3 with serum matrix, and serial dilutions of supplied standards were prepared. In addition, serum samples from control and gonadectomized rats and mice were analyzed in parallel to verify the suitability of the assay to measure both murine and rat $\mathrm{LH}$ and FSH. Diluted samples were incubated over night at $4{ }^{\circ} \mathrm{C}$ with antibody-immobilized fluorescent beads in a 96-well plate format. Biotinylated detection antibodies were added, samples were washed, incubated with streptavidin-phycoerythrin complexes and signals were recorded and analyzed using a Luminex 200 system (Luminex Corp., Austin, TX, USA).

\section{Histopathological analysis of tissue specimens}

Tissue was harvested and fixed at $4{ }^{\circ} \mathrm{C}$ in $4 \%$ paraformaldehyde for at least $6 \mathrm{~h}$. Six micrometer thick sections were cut from the paraffin-embedded tissue and transferred onto glass slides. After H\&E staining, histology was examined under an epifluorescence microscope (AxioPlan 2 Imaging System, Carl Zeiss, Jena, Germany), and photographs were taken with a connected digital camera (AxioCAM MRc) using the AxioVision 4.2 software (both Carl Zeiss).

\section{Statistical analysis}

Student's $t$-test or ANOVA was performed as indicated to reveal statistical significances. A $P<0.05$ was considered to be statistically significant.

\section{Results}

\section{In vitro efficacy of Gata4 RNAi}

The goal of this study was to generate a transgenic mouse expressing short hairpin RNA (shRNA) directed against Gata4 and to then examine the consequence of reduced GATA4 expression on the function of organs known to express this transcription factor. We first tested two different Gata4 shRNA constructs in murine C2C12 myoblasts. These cells express GATA4 and were transfected with the pcDNA6/TR and the pTER:shGata4 plasmid. Double-transfected cells were treated without or with $1,2 \cdot 5$, or $5 \mu \mathrm{g} / \mathrm{ml}$ doxycycline for 3 or 7 days respectively. Three days after application of $2.5 \mu \mathrm{g}$ doxycycline per $\mathrm{ml}$ medium or alternatively 7 days after treatment with $5 \mu \mathrm{g}$ doxycycline per $\mathrm{ml}$ medium, most efficient reduction in Gata4 protein expression was detected (Fig. 1C). The Gata4 siRNA sequence (TCTCGATATGTTTGATGAC) is almost identical to a human GATA4 siRNA (NCBI accession no. L34357; nt 852-870 relative to the transcription start site: TCTCGATATGTTTGACGAC) that has previously been shown to efficiently reduce GATA4 expression in human hepatoma Hep3B cells (Dame et al. 2004). Normal expression levels of Gata2 mRNA demonstrated that Gata4 siRNA is specific. A control siRNA that was not homologous to the Gata4 sequence (scrambled sequence) did not reduce Gata4 expression (data not shown). These results show that Gata4 siRNA can be expressed in an inducible manner and that it specifically reduces GATA4 expression (Fig. 1C).

\section{Generation of transgenic mice}

We next generated transgenic mice in which expression of Gata 4 can be repressed using inducible siRNA. Multiple coinjections of the TetR and the H1:G4 constructs into fertilized oocytes resulted in a total of 494 transfected oocytes and 121 offsprings. One male animal of the transgenic founder lines contained both H1:G4 and TetR. We also generated a line only harboring the TetR construct. However, H1:G4 single transgenic animals could not be generated, possibly due to embryonic lethality. Thus, the presence of the $T e t R$ may be required for the survival of embryos carrying the Gata4 shRNA transgene. Mice were then subsequently bred to generate a colony of mice harboring both transgenes (H1:G4/TetR). The integration pattern of this construct is somewhat complex and suggests that in addition to single copy integration the transgenes also integrated as multiple tandem repeats (Fig. 2). Based on the comparison of band intensities of transgene-derived fragments with a fragment from the murine $\beta$-globin gene in Southern blots, we estimated that the copy numbers of the transgenic constructs were between 10 and 15 . The fact that the pattern of DNA fragments in Southern blot analysis remained the same after several generations for both the H1:G4 and TetR transgene (siGata4) suggests that the two constructs co-integrated into the same single locus. 
A $\mathrm{H} 1: G 4$

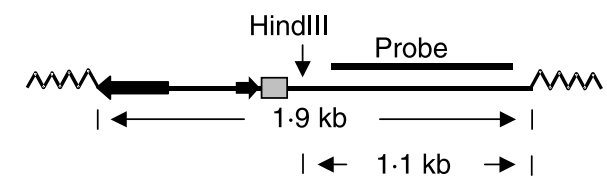

TetR

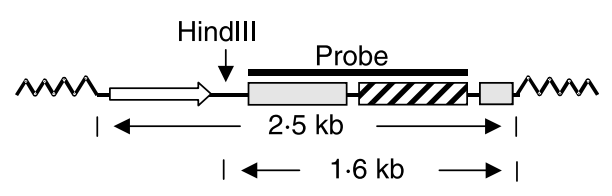

B

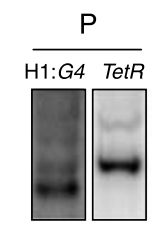

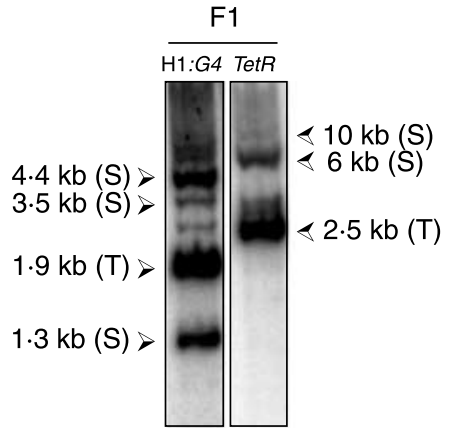

Figure 2 Generation of $\mathrm{H} 1: G 4 / T e t R$ double-transgenic mice (siGata4). (A) Gata4 shRNA (H1:G4 (1.9 kb)) and TetR expressing construct (TetR; $2.5 \mathrm{~kb}$ ) were used to generate transgenic mice. After Hindlll digestion of genomic DNA, the H1:G4 and TetR transgenes were identified by Southern blot and expected sizes for multi-copy integrations were observed, for the $\mathrm{H} 1: \mathrm{G} 4$ transgene $1.9 \mathrm{~kb}$ and for the TetR transgene $2.5 \mathrm{~kb}$. Other bands are due to the end fragments of the transgenic constructs. (B) Southern blot analysis of parental founder $(P)$ and $F 1 / F 2$ offspring. The integration patterns of the $\mathrm{H} 1: G 4$ and TetR transgenes are shown. The sizes of the bands depend on single integration (S) or various tandem integrations ( $\mathrm{T}$ ) of the transgene. In case of a single integration, the expected size for the H1:G4 transgene was $>1 \cdot 1 \mathrm{~kb}$. In the case of the TetR transgene the expected size was $>1.6 \mathrm{~kb}$. Multiple tandem integrations in $5^{\prime} \rightarrow 3^{\prime}$ configurations resulted in a $1.9 \mathrm{~kb}$ signal with respect to the $\mathrm{H} 1: G 4$ transgene and a $2.5 \mathrm{~kb}$ signal with respect to the TetR transgene. $A 3^{\prime} \rightarrow 5^{\prime}$ tandem integration configuration is expected to yield a $2 \cdot 2 \mathrm{~kb}$ signal for the $\mathrm{H1}: \mathrm{G} 4$ and a $3 \cdot 2 \mathrm{~kb}$ signal for the $T e t R$ transgene respectively.

Transgenic mice harboring the H1:G4 and the TetR expressions constructs appeared to be clinically normal, but breeding resulted only incidentally in pregnancy. However, some transgenic females ( 7 out of a total of 40 females) died within a period of 6 month without exhibiting a pathophysiological phenotype. Since siGata4 transgenic mice not treated with doxycycline revealed up to $25 \%$ reduction of Gata 4 mRNA levels in the heart, we speculate that the increase in mortality of females is likely due to leaky expression of the Gata4 siRNA in any specific organ system, but unlikely due to heart failure as shown in experiments described below. Of note, application of doxycycline to wild-type mice did not affect the expression of Gata 4 mRNA or Gata4 downstream targets in heart, demonstrating that doxycycline itself does not modulate Gata4 expression. Mice expressing only the TetR construct were phenotypically normal and showed normal fertility, as previously described in the literature (Corbel \& Rossi 2002, Szulc et al. 2006, Seibler et al. 2007). TetR transgenic mice did not reveal reductions in cardiac Gata4 expression. There is also no other evidence for changes in gene expression patterns in TetR transgenic mouse lines (Corbel \& Rossi 2002, Szulc et al. 2006, Seibler et al. 2007).

\section{In vivo suppression of Gata4 by shRNA in the heart}

Adult wild-type and transgenic siGata4 mice were treated with $20 \mathrm{mg}$ doxycycline per $\mathrm{ml}$ drinking water for different time periods (14-70 days). In the heart, we observed a time-dependent reduction of Gata4 mRNA expression, which reached significance 5 weeks after induction of Gata4 shRNA. Suppression of GATA4 mRNA and protein (Fig. 3A and B) was associated with reduced expression of the known cardiac GATA4 target genes Anf and Bmp4 (Fig. 3C; Grepin et al. 1994, Nemer \& Nemer 2003). Surprisingly, the expression of the $\alpha-M h c$ gene, another known GATA4 downstream target (Molkentin et al. 1994, Charron et al. 1999), was not affected. Most importantly, however, transgenic animals with induced Gata4 shRNA did not show cardiac failure. Cardiac function was monitored by electrocardiography (in cooperation with $\mathrm{Dr} \mathrm{H}$ Kasahara, University of Florida), which was normal (data not shown), and furthermore, histological examination did not reveal morphological changes (Fig. 3D). Thus, reduction of Gata4 expression to levels $<30 \%$ of wild type (as analyzed up to day 70) did not impair the function of non-stress exposed hearts. Unexpectedly, the overall expression of $\alpha-M h c$ increased both in wild-type and transgenic siGata4 mice during doxycycline treatment. It appears unlikely that this effect is mediated by up-regulation of Gata6, since Gata6 mRNA levels were normal in transgenic mice 29 days after induction of Gata4 shRNA (Fig. 3E). We consistently found that induction of Gata4 shRNA expression was associated with a significant increase in Oas2 gene expression (Fig. 3B). This is consistent with previous studies demonstrating that expression of shRNAs can activate the interferon response (Bridge et al. 2003, Sledz et al. 2003). However, the scientific impact of transgenic mice expressing shRNA against a gene of interest is supported by the recent finding that endogenous microRNA pathways are preserved in such models (Sasaguri et al. 2009). 


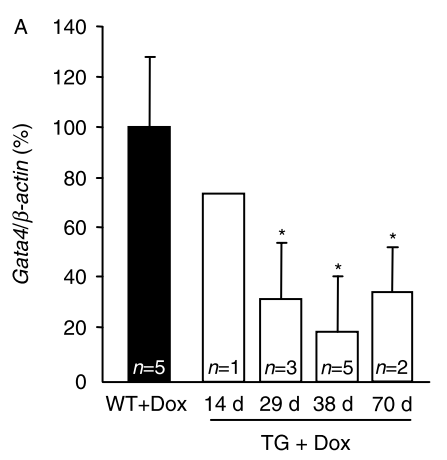

B

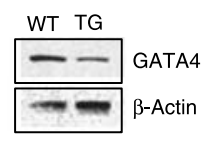

D
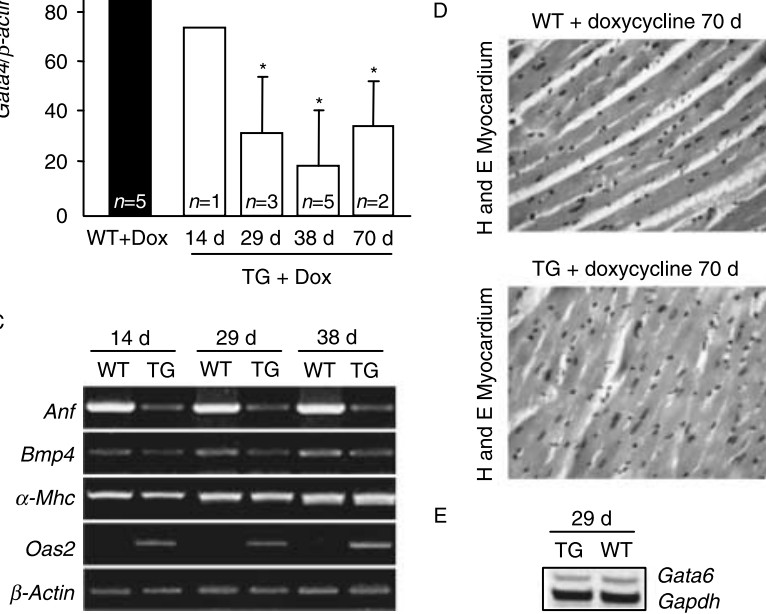

Figure 3 In vivo cardiac GATA4 suppression by shRNA. Wild-type (WT) and siGata4 transgenic (TG) mice were treated with doxycycline for 14, 29, 38, and 70 d respectively. (A) Quantitative PCR analysis of Gata4 mRNA expression (means \pm s.D.,

${ }^{*} P<0 \cdot 05$ ). (B) GATA4 suppression in the heart taken 38 days after induction of Gata4 shRNA was confirmed by western blot. (C) Representative conventional RT-PCR analysis of Anf, $\alpha-M h c$, and Oas2 expression in heart tissue specimens, obtained from WT and siGata4 TG mice treated with doxycycline for 14, 29, or 38 days respectively. (D) H\&E staining of the myocardiac tissue specimens from siGata4 transgenic versus wild-type mice after treatment with doxycycline for 70 days. (E) Analysis of Gata6 mRNA expression in siGata4 TG and wild-type mice treated with doxycycline for 29 days.

\section{Effects of Gata4 shRNA on Gata4 downstream target genes in normally developed female and male gonads}

Next, we examined whether induction of Gata4 shRNA affect expression of GATA4 downstream targets in the gonads. As shown in Fig. 4, activation of the H1:G4 transgene resulted in strong reduction of Gata 4 mRNA in the ovary and testis at day 38. GATA4 protein expression in the testis was almost abolished (Fig. 4A). As in the heart, we also observed an induction of the interferon response gene Oas-2 both in the testis and ovary (Fig. 3A and C). In the testis, Gata4 mRNA reduction was associated with reduced Mis and Star gene expression, two previously identified GATA4 target genes (Tremblay \& Viger 2001). By contrast, Gata 4 mRNA reduction in the ovary was associated only with moderate changes in Star and Mis gene expression (Fig. 4B and C). Although Gata6 expression was not changed, this finding itself does not allow conclusions as to whether GATA6 functionally compensates the disturbance of GATA4 function in the ovary. However, this finding argues against global down-regulation of gene expression by off-target effects. To elucidate consequences on steroidogenesis, blood samples were analyzed for hormone concentrations. The analysis revealed similar concentrations of FSH in transgenic females with induced Gata4 shRNA (mean $15472 \mathrm{pg} / \mathrm{ml}$ ) versus those without doxycycline (mean $14828 \mathrm{pg} / \mathrm{ml}$ ) versus wild-types $(15136 \mathrm{pg} / \mathrm{ml})$. Similarly, circulating LH concentrations did not differ between transgenic females with induced Gata4 shRNA (mean $415 \mathrm{pg} / \mathrm{ml}$ ) versus those without doxycycline (mean $668 \mathrm{pg} / \mathrm{ml}$ ) versus wild-types $(347 \mathrm{pg} / \mathrm{ml})$. Because the effect of reduced GATA4 expression on target genes was more pronounced in the testis, reduced fertility in transgenic mice, in which the Gata4 siRNA was not induced by doxycycline, may be caused rather by 'leaky' expression in males.

\section{Development of ovarian tumors (teratoma) in doxycycline induced Gata4 shRNA transgenic females}

Of note, 2 out of 20 siGata 4 transgenic females treated with doxycycline to induce Gata4 shRNA developed ovarian teratoma (Fig. 5). One well-differentiated teratoma was found 14 days after activation of the H1:G4 transgene. This teratoma was composed of structures predominantly derived from meso- and ectoderm (Fig. 5A-G). Another teratoma was obtained from a transgenic female mouse treated with doxycycline for 21 days. This teratoma was less differentiated and contained large areas of necrosis (Fig. 5H-K). No tumorigenesis was observed in wild-type mice (with or without doxycycline treatment).

Taken together, in vivo Gata4 shRNA expression showed differential effects of GATA4 on its downstream hormone-encoding genes in male versus female gonads and caused an increased incidence of teratoma in the ovary.

\section{Discussion}

\section{Transgenic mouse with inducible Gata4 shRNA}

Herein, we describe the first in vivo model of inducible Gata4 shRNA. The transgenic mouse line is characterized by a stably integrated shRNA construct directed against Gata4 that is under the control of a TetR repressor and inducible by doxycycline. Our decision to develop a mouse model with inducible shRNA against Gata4 allowing for dose- and/or time-dependent suppression of Gata4 expression without restriction to a specific organ system, was based on several considerations: first, we expected that a critical level of GATA4 is required for normal cardiac function ( $\mathrm{Pu}$ et al. 2004, Zeisberg et al. 2005, Bisping et al. 2006, Oka et al. 2006, 

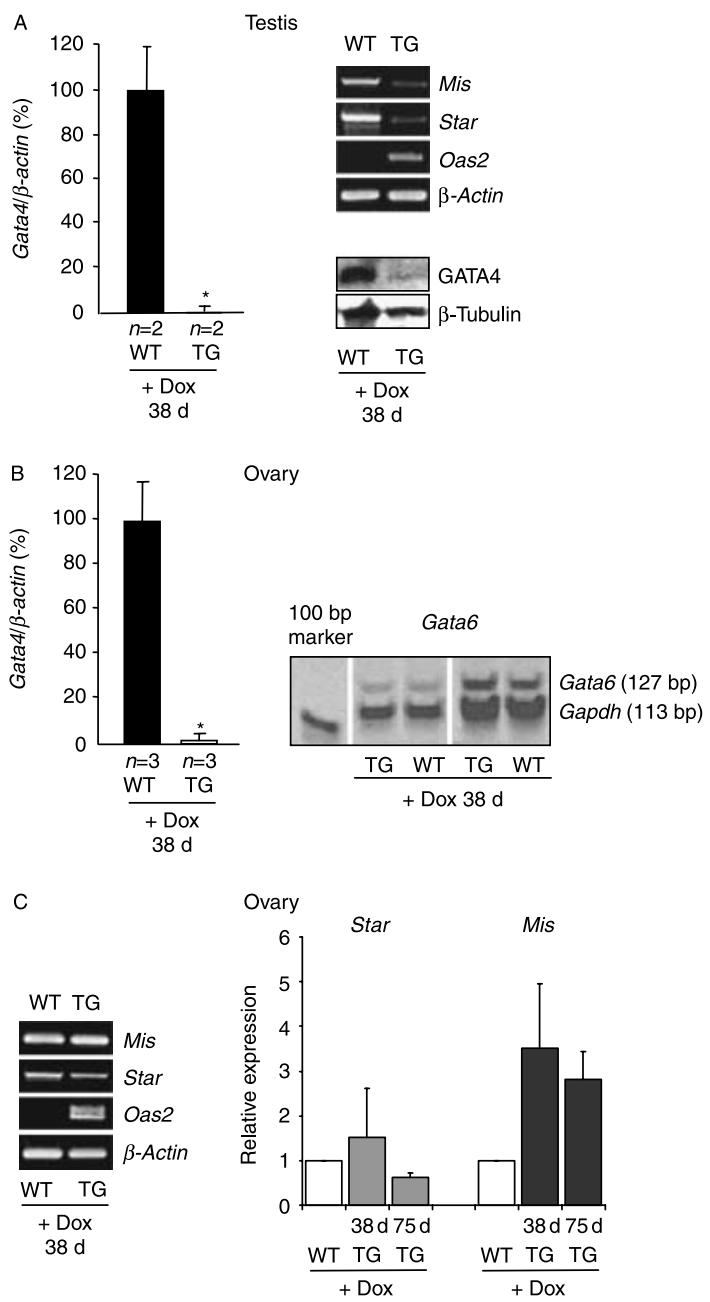

Figure 4 Effects of in vivo Gata4 shRNA expression on GATA4 target genes in the reproductive organs. WT and siGata4 TG mice were treated with doxycycline-containing water to induce $\mathrm{H1}$ : G4 over a time period of 38 days. (A) Expression of Gata4 and GATA4 target genes in the testis. Quantitative PCR analysis of Gata4 mRNA expression (left panel; means \pm s.D., ${ }^{*} P<0.01$ ) and conventional RT-PCR (right panel) for expression analysis of Mis, Star, Oas2, and $\beta$-actin in WT versus siGata4 TG mice. Western blot analysis of GATA4 expression after 38 days of $\mathrm{H} 1: \mathrm{G} 4$ induction (lower right panel). (B) Expression of Gata4 in the ovary measured by quantitative PCR - indicates highly significant reduction of Gata4 mRNA expression in siGata4 TG versus WT mice (left panel; means \pm s.D., ${ }^{\star} P<0 \cdot 01$ ). Conventional RT-PCR analysis indicates no changes in Gata6 mRNA expression levels after 38 days of doxycycline treatment in TG versus WT mice (right panel). (C) Conventional RT-PCR analysis (left panel) for Mis, Star, Oas2, and $\beta$-actin expression in siGata4 TG versus WT mice. Real-time PCR analysis excluded significant changes in Star or Mis mRNA expression after 38 or 70 days of induction of Gata4 shRNA (ANOVA).

Jay et al. 2007); and second, regarding the identification of GATA4 mutations in humans (Pehlivan et al. 1999, Garg et al. 2003, Nemer et al. 2006, Schluterman et al. 2007, Tomita-Mitchell et al. 2007), we were interested whether Gata4 levels of $<50 \%$ of normal would be associated with non-cardiac disorders, in particular in the endocrine system.

In our initial experiments, we identified a murine Gata4 siRNA sequence that significantly and specifically reduced GATA4 mRNA and protein expression in murine myoblasts. We also demonstrated that the TetR expression vector is tightly regulated by doxycycline in a dose-dependent manner (Fig. 1). The murine Gata4 siRNA sequence is almost identical to a human GATA4 siRNA sequence, which effectively reduced GATA4 in human hepatoma cells (Dame et al. 2004).

Adult mice harboring the $\mathrm{H1G4/TetR}$ or the TetR transgenes were phenotypically normal. However, transgenic siGata4 female mice older than 3 months revealed an increased rate of mortality compared with wild-type mice. However, the reason for increased mortality remains unclear at this point. Since Gata4 is expressed in a variety of organs, we attribute these observations to leaky expression of the $\mathrm{H} 1 G 4$ transgene, which in fact is suggested by reduced Gata 4 mRNA levels in the heart. Leaky expression of the transgene could also contribute to the observed breeding problems. Importantly, however, Gata4 shRNA could be successfully induced in a time-dependent manner in animals after subjecting transgenic mice to doxycyclinecontaining drinking water (Figs 3 and 4). The maximum suppression of endogenous Gata4 expression showed tissue-specific differences, e.g. reproductive organs revealed a more dramatic reduction in Gata4 mRNA expression than the heart. The differences in Gata4 reduction could be due to lower expression levels of Gata4 in the male and female gonads versus the heart, to tissue-specific differences in in vivo shRNA expression (Oberdoerffer et al. 2005, Seibler et al. 2007, Sasaguri et al. 2009), or to differences in the uptake of doxycycline in the gonads. The time course experiment revealed the most dramatic effect on Gata4 expression after 38 days of shRNA induction in transgenic mice. The reason for this relatively long time period is unclear at the moment, but could in part be due to slow turnover of cells combined with a long half-life of GATA4 mRNA and protein in certain tissues.

\section{Reduction of Gata4 expression by $80 \%$ does not impair the function of non-stress induced adult heart}

We first analyzed the effect of Gata4 shRNA in the heart. Even at $80 \%$ reduction of Gata4 mRNA expression (after 38 days) and after long-term Gata4 shRNA expression over a period of 70 days, transgenic mice did not show cardiac failure and revealed normal electrocardiography and histology of the myocardiac tissue (Fig. 4D). This observation is consistent with a recent report by Oka et al. (2006) describing the phenotype of Gata4-loxP-targeted mice crossed with 

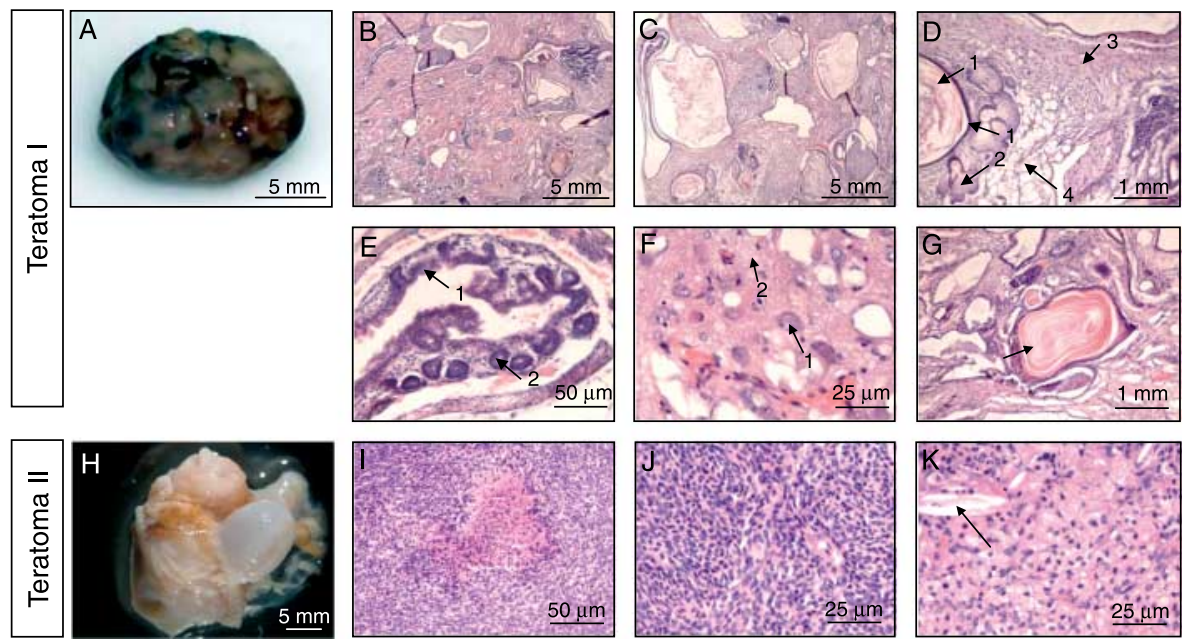

Figure 5 Ovarian teratoma from female siGata4 transgenic mice with induced Gata4 shRNA. (A) Macroscopy of a mature teratoma (I) harvested 14 days after induction of Gata4 shRNA. (B) and (C) H\&E overviews show characteristic solid and cystic structures of all three germ layers. (D) Structures derived from the ectoderm include cysts that are lined with weakly keratinized squamous epithelium (1), adjoined integumentary system with persipiratory glands (2), and neuronal tissue (3). Among mesodermal structures, fatty tissue (4) and connective tissue were found. (E) At higher magnification some clearly under-represented areas show structures derived from the endoderm, such as columnar surface epithelium (1) and short crypts (2). (F) Differentiated neuronal cells (1) are located besides glia cells and matrix (2). (G) As indicated by the arrow, a cyst of ectodermal origin shows intense cornification. $(\mathrm{H})$ Macroscopy of an immature teratoma (II) harvested 21 days after induction of Gata4 shRNA. (I) This teratoma contains connective tissue that shows only a few small vessels and exhibits focal necrosis. $(\mathrm{J})$ The tumor consists of a dense, homogenous micro- and dark-cellular tissue without further differentiation. $(\mathrm{K})$ The arrow indicates an area of phagocytic reaction with foam cells and multinuclear giant cells with incorporated cholesterol spicules.

$\alpha-M h c$ promoter driven Cre transgenes ( Gata4fl/ $f^{\alpha-\text { Mhc-Cre }}$ ) to achieve conditional cardiac Gata4 deletion. The

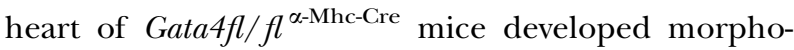
logically normal and showed a $70 \%$ suppression of cardiac GATA4 levels, which is therefore most appropriate for comparison with our siGata4 transgenic mouse. Other models with heterozygous Gata4 insufficiency show disorders in cardiac development (Bisping et al. 2006, Jay et al. 2007). The difference, however, is that in the haploinsufficiency studies the phenotype due to reduction in Gata4 expression could mainly result from developmental defects, while in transgenic mice and in Gata4fl/ $f^{\alpha \text {-Mhc-Gre }}$ mice expression of Gata4 during development was normal. Our siGata4 transgenic mice demonstrate that under normal conditions the depletion of up to $80 \%$ of Gata 4 does not result in cardiac failure in a morphologically normal developed heart. These results may have high clinical impact, since GATA4 mRNA and protein levels vary by approximately twofold between normal and failing human hearts (Hall et al. 2004), and doxorubicin, which is broadly used for cancer treatment, causes cardiotoxic heart failure due to GATA4 depletion in wild-type mice (Aries et al. 2004). Of note, in models of pressure overload or exercise stimulation GATA4 depletion of about $70 \%$ (Gata4fl) $f^{\alpha \text {-Mhc-Cre }}$ mice) results in cardiac decompensation and dilatation (Oka et al. 2006). Another transgenic mouse strain analyzed by Oka et al. (2006), in which Gata4-loxPtargeted mice were crossed with the $\beta$-Mhc promoter driven Cre, revealed a 90-95\% depletion of GATA4 protein and exhibited cardiac insufficiency even under normal (non-stress induced) conditions.

To further elucidate molecular consequences of in vivo Gata4 suppression, we examined three heartspecific genes that were previously identified to be regulated by GATA4. Among these genes, $B m p 4$ and Anf were expressed at lower levels in transgenic mice compared with wild-type mice, while the $\alpha$-Mhc gene was expressed at similar levels (Fig. 3). It is possible that suppression of Anf and Bmp4 requires lower concentrations of GATA4 compared with $\alpha-M h c$. This may also be due to differences in the affinity of GATA4 to regulatory elements of these genes. Alternatively, other activities may compensate for decreased levels of Gata4 in $\alpha-M h c$ gene expression. GATA6 is a candidate factor that has been discussed to compensate for GATA4 deficiency in various experimental models (Kuo et al. 1997, Morrisey et al. 1998, Bisping et al. 2006, Oka et al. 2006). Our data indicate that Gata6 expression 
is unaltered in siGata4 transgenic mice (Fig. 3E). In conclusion, our transgenic model together with previous studies provides evidence that a critical level of Gata4 is required for the function of the non-stressed adult heart and that $20 \%$ of normal Gata4 levels is sufficient for heart function (Bisping et al. 2006, Oka et al. 2006).

\section{In vivo evidence for a role of Gata4 in reproduction}

Our observation of a reduced breeding efficacy in the siGata4 transgenic colony and previous observations of Gata4 mRNA expression in the gonads of developing and adult mice (Arceci et al. 1993, Morrisey et al. 1996) led us to examine the expression of Gata4 and putative target genes in the testis and ovary. Of note, reduction of Gata4 expression was more pronounced in the gonads compared with heart (Fig. 4).

Induced expression of Gata4 shRNA resulted in a significant reduction of StAR and MIS gene expression in the testis. Very recently, Gata4 has been found to be required for sex steroidogenic cell development in the fetal mouse (Bielinska et al. 2007). In the developing and adult male gonad of mouse and human, GATA4 is expressed in somatic cells, including testicular, Leydig, and Sertoli cells. Gata 4 mRNA levels were found to decrease during postnatal development in Sertoli, but not in Leydig cells (Viger et al. 1998, Ketola et al. 2000, 2002). Additionally, GATA4 expression has been found - although somewhat inconsistently - in human and murine fetal germ cells and human spermatogonia (Arceci et al. 1993, Viger et al. 1998, Ketola et al. 2000). In human germ cells, however, GATA4 expression is down-regulated after puberty (Ketola et al. 2000). Owing to embryonic lethality of $\mathrm{Gata}^{-/-}$mice (Kuo et al. 1997, Molkentin et al. 1997) and gonadal sex reversal in mice with only a single functional allele of Gata4 $\left(\mathrm{Gata}^{k i /+} X Y^{A K L}\right.$ mice that develop ovaries or ovotestes; Bouma et al. 2007), data on the in vivo implication of GATA4 in the normal developed gonads are limited (Kuo et al. 1997, Molkentin et al. 1997). However, it has been shown that interactions between GATA4 and its co-factor FOG2 and correct dosage of both factors are necessary for normal testicular development (Tevosian et al. 2002, Bouma et al. 2007). Most recent data indicate that Gata 4 is required in a cell autonomous fashion for proper differentiation of Leydig cells, independently from Sertoli cell-derived factors (Bielinska et al. 2007). Since normal GATA4 expression in Leydig cells increases when puberty starts and Leydig cells produce androgens necessary for spermatogenesis (Ketola et al. 2000), reduced fertility in the siGata4 transgenes may be caused by a defect in Leydig cell function. This is supported by the observation that GATA4 downstream target genes involved in gonadal somatic cell function and steroidogenesis, including Mis or Star (Tremblay \& Viger 1999, Hiroi et al. 2004), were down-regulated in siGata4 induced mice. An additional plausible mechanism for disorders in spermatogenesis is a disturbed activation of the reproductive homeobox on the $X$ chromosome gene by Gata 4 deficiency in Sertoli cells (Bhardwaj et al. 2008). In humans, data on disorders in the development or function of the male gonads have not been associated with GATA4 yet, but appear likely, since some mutations affect the activity of target gonadal promoters in vitro (Bouchard et al. 2009). Of note, the currently known GATA4 mutations seem to retain their ability to interact and to cooperate with major gonadal partners (SF1-NR5A1 and LRH-1/ NR5A2), thereby partially compensating the loss of intrinsic GATA4 transcriptional activity (Bouchard et al. 2009). Moreover, in androgen resistance, GATA4 expression in Sertoli and germ cells is weak or totally absent (Ketola et al. 2000).

In the murine ovary, Gata4 expression has been detected in granulosa and thecal cells (Heikinheimo et al. 1997), where it is regulated by gonadotrophins (Kwintkiewicz et al. 2007). Interestingly, FSH increases transcription of the Gata4 gene (Kwintkiewicz et al. 2007). While Gata4 is abundantly expressed in granulosa cells of primary and early antral follicles during the period of active proliferation, it is rapidly downregulated when granulosa cell proliferation ceases at ovulation, atresia, or luteinization (Heikinheimo et al. 1997, Laitinen et al. 2000). Low levels of Gata4 mRNA are also expressed in the germinal epithelium and interstitial cells (Heikinheimo et al. 1997). We observed only minor changes in Starand Mis mRNA levels in the ovaries of mice expressing Gata4 siRNA (Fig. 4C). The lack of Mis suppression in the ovary (Fig. 4C) may confirm previous in vitro data indicating that GATA4 and FOG2 play a distinctive role in the ovary. FOG2 is able to repress the GATA4 mediated in vitro transactivation of the Mis promoter (Anttonen et al. 2003). Thus, Gata4 siRNA may not affect Mis gene expression in the adult ovary. Although GATA4 has been shown to control genes that are involved in the maturation and/or maintenance of granulosa cells within early follicles (Heikinheimo et al. 1997), normal levels of FSH and LH make it rather unlikely that female fertility is affected by Gata4 suppression.

\section{Ovarian teratoma in female siGata4 transgenic mice indicate a role of Gata4 as tumor suppressor}

The data presented here demonstrate for the first time that Gata4 deficiency may play a role in tumorigenesis of the ovary. A total of $10 \%$ doxycycline induced Gata4 shRNA transgenic female mice developed ovarian teratoma (Fig. 5), while no tumor formation was observed in non-transgenic mice, non-transgenic mice 
treated with doxycycline, or in transgenic mice not exposed to doxycycline. There is currently no evidence from more than 16 transgenic mouse models of stable, inducible, or conditional RNAi for the development of teratoma as a non-specific side effect (Hasuwa et al. 2002, Oberdoerffer et al. 2005, Seibler et al. 2005) for review: Kühn et al. (2007). Although the mature and immature teratomas in Gata4 shRNA transgenic mice contained structures from all three germ layers, the contribution from the endoderm was rather low. The teratomas observed here are similar to those formed in nude mice after injection of Gata4 deficient ES cells (Soudais et al. 1995). GATA4 expression has been described in pediatric yolk sac tumors originating from either gonadal or extragonadal sites, but not in mature teratomas (Siltanen et al. 1999). The role of GATA4 in tumorigenesis is not well understood and may vary depending on the tissue from which the tumor originates. On the one hand, GATA4 has been suggested as a tumor suppressor gene because epigenetic silencing of the GATA4 gene resulted in the down-regulation of anti-tumor target genes. For example, in gastrointestinal tumor cell lines it became evident that silencing of anti-tumor genes (trefoilfactors, inhibin- $\alpha$ and disabled-2) due to GATA4 downregulation, methylation, or histone modifications is involved in tumor cell proliferation (Akiyama et al. 2003, Wakana et al. 2006, Viger et al. 2008). On the other hand, GATA4 also exhibits anti-apoptotic activity (Grepin et al. 1997, Laitinen et al. 2000, Aries et al. 2004). Nonetheless, the siGata 4 transgenic animals studied here provide the first direct in vivo evidence for an increased risk of ovarian teratoma formation due to reduced expression of GATA4 or one of its target genes. In human females with Ala189Val FSH receptor mutations, a complete block of FSH action is associated with a strong reduction of GATA4 protein expression in the ovary. In these patients an increased risk for teratoma formation (or generation of other ovary associated tumors) should be considered (Vaskivuo et al. 2002).

In conclusion, our study demonstrates that transgenic mice expressing shRNA represents a useful model system to study the effect of reduced transcription factor expression in adult mice. We provide in vivo evidence that Gata4 exhibits a dose-dependent effect on cardiac function. Of note, GATA4 differentially affects down-stream targets in the male versus female gonads. Finally, our results suggest a higher risk of developing ovary-associated teratomas in Gata4 deficiency. These findings should be considered in counseling patients with inherited or acquired GATA4 deficiency.

\section{Declaration of interest}

The authors declare that there is no conflict of interest that would prejudice the impartibility of this scientific work.

\section{Funding}

American Heart Association and the National Institutes of Health (RO1-DK052356 to J B); Studienstiftung des Deutschen Volkes (Fellowship to B T); Deutscher Akademischer Austauschdienst (Fellowship to B T); Fritz Thyssen Stiftung (AZ. 10·05·2 162 to C D).

\section{Acknowledgements}

We thank Dr van der Wetering for providing the pTER+ plasmid, and Mike Rule and the UF transgenic core facility for generating the transgenic mice. We also thank Dr Hideko Kasahara of UF for performing the electrocardiography. We also appreciate the discussion of the data and the manuscript by the members of our laboratories, in particular Hannes Sallmon and Martin Klar.

\section{References}

Akiyama Y, Watkins N, Suzuki H, Jair KW, van Engeland M, Esteller M, Sakai H, Ren CY, Yuasa Y, Herman JG et al. 2003 GATA-4 and GATA-5 transcription factor genes and potential downstream antitumor target genes are epigenetically silenced in colorectal and gastric cancer. Molecular and Cellular Biology 23 8429-8439.

Anttonen M, Ketola I, Parviainen H, Pusa AK \& Heikinheimo M 2003 FOG-2 and GATA-4 are coexpressed in the mouse ovary and can modulate Mullerian-inhibiting substance expression. Biology of Reproduction 68 1333-1340.

Arceci RJ, King AA, Simon MC, Orkin SH \& Wilson DB 1993 Mouse GATA-4: a retinoic acid-inducible GATA-binding transcription factor expressed in endodermally derived tissues and heart. Molecular and Cellular Biology 13 2235-2246.

Aries A, Paradis P, Lefebvre C, Schwartz RJ \& Nemer M 2004 Essential role of GATA-4 in cell survival and drug-induced cardiotoxicity. PNAS 101 6975-6980.

Bantounas I, Phylactou LA \& Uney JB 2004 RNA interference and the use of small interfering RNA to study gene function in mammalian systems. Journal of Molecular Endocrinology 33 545-557.

Bhardwaj A, Rao MK, Kaur R, Buttigieg MR \& Wilkinson MF 2008 GATA factors and androgen receptor collaborate to transcriptionally activate the Rhox 5 homeobox gene in Sertoli cells. Molecular and Cellular Biology 28 2138-2153.

Bielinska M, Seehra A, Toppari J, Heikinheimo M \& Wilson DB 2007 GATA-4 is required for sex steroidogenic cell development in the fetal mouse. Developmental Dynamics 236 203-213.

Bisping E, Ikeda S, Kong SW, Tarnavski O, Bodyak N, McMullen JR, Rajagopal S, Son JK, Ma Q, Springer Z et al. 2006 Gata4 is required for maintenance of postnatal cardiac function and protection from pressure overload-induced heart failure. PNAS 103 14471-14476.

Bouchard MF, Taniguchi H \& Viger RS 2009 The effect of human GATA4 gene mutations on the activity of target gonadal promoters. Journal of Molecular Endocrinology 42 149-160.

Bouma GJ, Washburn LL, Albrecht KH \& Eicher EM 2007 Correct dosage of Fog2 and Gata4 transcription factors is critical for fetal testis development in mice. PNAS 104 14994-14999.

Bridge AJ, Pebernard S, Ducraux A, Nicoulaz AL \& Iggo R 2003 Induction of an interferon response by RNAi vectors in mammalian cells. Nature Genetics 34 263-264.

Bungert J, Dave U, Lim KC, Lieuw KH, Shavit JA, Liu Q \& Engel JD 1995 Synergistic regulation of human beta-globin gene switching by locus control region elements HS3 and HS4. Genes and Development 9 3083-3096.

Bungert J, Tanimoto K, Patel S, Liu Q, Fear M \& Engel JD 1999 Hypersensitive site 2 specifies a unique function within the human beta-globin locus control region to stimulate globin gene transcription. Molecular and Cellular Biology 19 3062-3072. 
Charron F, Paradis P, Bronchain O, Nemer G \& Nemer M 1999 Cooperative interaction between GATA- 4 and GATA- 6 regulates myocardial gene expression. Molecular and Cellular Biology 19 4355-4365.

Corbel SY \& Rossi FM 2002 Latest developments and in vivo use of the Tet system: ex vivo and in vivo delivery of tetracycline-regulated genes. Current Opinion in Biotechnology 13 448-452.

Dame C, Sola MC, Lim KC, Leach KM, Fandrey J, Ma Y, Knopfle G, Engel JD \& Bungert J 2004 Hepatic erythropoietin gene regulation by GATA-4. Journal of Biological Chemistry 279 2955-2961.

Dame C, Kirschner KM, Bartz KV, Wallach T, Hussels CS \& Scholz H 2006 Wilms tumor suppressor, Wt1, is a transcriptional activator of the erythropoietin gene. Blood 107 4282-4290.

E LL, Zhao YS, Guo XM, Wang CY, Jiang H, Li J, Duan CM \& Song Y 2006 Enrichment of cardiomyocytes derived from mouse embryonic stem cells. Journal of Heart and Lung Transplantation 25 664-674.

Garg V, Kathiriya IS, Barnes R, Schluterman MK, King IN, Butler CA, Rothrock CR, Eapen RS, Hirayama-Yamada K, Joo K et al. 2003 GATA4 mutations cause human congenital heart defects and reveal an interaction with TBX5. Nature 424 443-447.

Grepin C, Dagnino L, Robitaille L, Haberstroh L, Antakly T \& Nemer M 1994 A hormone-encoding gene identifies a pathway for cardiac but not skeletal muscle gene transcription. Molecular and Cellular Biology 14 3115-3129.

Grepin C, Nemer G \& Nemer M 1997 Enhanced cardiogenesis in embryonic stem cells overexpressing the GATA-4 transcription factor. Development 124 2387-2395

Hall JL, Grindle S, Han X, Fermin D, Park S, Chen Y, Bache RJ, Mariash A, Guan Z, Ormaza S et al. 2004 Genomic profiling of the human heart before and after mechanical support with a ventricular assist device reveals alterations in vascular signaling networks. Physiological Genomics 17 283-291.

Hasuwa H, Kaseda K, Einarsdottir T \& Okabe M 2002 Small interfering RNA and gene silencing in transgenic mice and rats. FEBS Letters 532 227-230.

Heikinheimo M, Ermolaeva M, Bielinska M, Rahman NA, Narita N, Huhtaniemi IT, Tapanainen JS \& Wilson DB 1997 Expression and hormonal regulation of transcription factors GATA- 4 and GATA-6 in the mouse ovary. Endocrinology 138 3505-3514.

Hirayama-Yamada K, Kamisago M, Akimoto K, Aotsuka H, Nakamura Y, Tomita H, Furutani M, Imamura S, Takao A, Nakazawa M et al. 2005 Phenotypes with GATA4 or NKX2.5 mutations in familial atrial septal defect. American Journal of Medical Genetics. Part A 135 47-52.

Hiroi H, Christenson LK \& Strauss JF III 2004 Regulation of transcription of the steroidogenic acute regulatory protein (StAR) gene: temporal and spatial changes in transcription factor binding and histone modification. Molecular and Cellular Endocrinology 215 119-126.

Jay PY, Bielinska M, Erlich JM, Mannisto S, Pu WT, Heikinheimo M \& Wilson DB 2007 Impaired mesenchymal cell function in Gata4 mutant mice leads to diaphragmatic hernias and primary lung defects. Developmental Biology 301 602-614.

Ketola I, Pentikainen V, Vaskivuo T, Ilvesmaki V, Herva R, Dunkel L, Tapanainen JS, Toppari J \& Heikinheimo M 2000 Expression of transcription factor GATA-4 during human testicular development and disease. Journal of Clinical Endocrinology and Metabolism 85 3925-3931.

Ketola I, Anttonen M, Vaskivuo T, Tapanainen JS, Toppari J \& Heikinheimo M 2002 Developmental expression and spermatogenic stage specificity of transcription factors GATA-1 and GATA-4 and their cofactors FOG-1 and FOG-2 in the mouse testis. European Journal of Endocrinology 147 397-406.

Kühn R, Streif S \& Wurst W 2007 RNA interference in mice. Handbook of Experimental Pharmacology 178 147-174.

Kuo CT, Morrisey EE, Anandappa R, Sigrist K, Lu MM, Parmacek MS, Soudais C \& Leiden JM 1997 GATA4 transcription factor is required for ventral morphogenesis and heart tube formation. Genes and Development 11 1048-1060.
Kwintkiewicz J, Cai Z \& Stocco C 2007 Follicle-stimulating hormoneinduced activation of Gata4 contributes in the up-regulation of Cyp19 expression in rat granulosa cells. Molecular Endocrinolgy 21 933-947.

Laitinen MP, Anttonen M, Ketola I, Wilson DB, Ritvos O, Butzow R \& Heikinheimo M 2000 Transcription factors GATA-4 and GATA-6 and a GATA family cofactor, FOG-2, are expressed in human ovary and sex cord-derived ovarian tumors. Journal of Clinical Endocrinology and Metabolism 85 3476-3483.

Li G, Lim KC, Engel JD \& Bungert J 1998 Individual LCR hypersensitive sites cooperate to generate an open chromatin domain spanning the human beta-globin locus. Genes to Cells $\mathbf{3}$ $415-429$.

Li L, Takemura G, Li Y, Miyata S, Esaki M, Okada H, Kanamori H, Khai NC, Maruyama R, Ogino A et al. 2006 Preventive effect of erythropoietin on cardiac dysfunction in doxorubicin-induced cardiomyopathy. Circulation 113 535-543.

Lowry JA \& Atchley WR 2000 Molecular evolution of the GATA family of transcription factors: conservation within the DNA-binding domain. Journal of Molecular Evolution 50 103-115.

Manna PR, Pakarinen P, El-Hefnawy T \& Huhtaniemi IT 1999 Functional assessment of the calcium messenger system in cultured mouse Leydig tumor cells: regulation of human chorionic gonadotropin-induced expression of the steroidogenic acute regulatory protein. Endocrinology 140 1739-1751.

Manuylov NL, Fujiwara Y, Adameyko II, Poulat F \& Tevosian SG 2007 The regulation of Sox9 gene expression by the GATA4/FOG2 transcriptional complex in dominant XX sex reversal mouse models. Developmental Biology 307 356-367.

Molkentin JD 2000 The zinc finger-containing transcription factors GATA-4, -5 , and -6 . Ubiquitously expressed regulators of tissue-specific gene expression. Journal of Biological Chemistry $\mathbf{2 7 5}$ 38949-38952.

Molkentin JD, Kalvakolanu DV \& Markham BE 1994 Transcription factor GATA-4 regulates cardiac muscle-specific expression of the alpha-myosin heavy-chain gene. Molecular and Cellular Biology 14 4947-4957.

Molkentin JD, Lin Q, Duncan SA \& Olson EN 1997 Requirement of the transcription factor GATA4 for heart tube formation and ventral morphogenesis. Genes and Development 11 1061-1072.

Morrisey EE, Ip HS, Lu MM \& Parmacek MS 1996 GATA-6: a zinc finger transcription factor that is expressed in multiple cell lineages derived from lateral mesoderm. Developmental Biology 177 309-322.

Morrisey EE, Tang Z, Sigrist K, Lu MM, Jiang F, Ip HS \& Parmacek MS 1998 GATA6 regulates HNF4 and is required for differentiation of visceral endoderm in the mouse embryo. Genes and Development 12 3579-3590.

Nemer G \& Nemer M 2003 Transcriptional activation of BMP-4 and regulation of mammalian organogenesis by GATA- 4 and -6 . Developmental Biology 254 131-148.

Nemer G, Fadlalah F, Usta J, Nemer M, Dbaibo G, Obeid M \& Bitar F 2006 A novel mutation in the GATA4 gene in patients with tetralogy of Fallot. Human Mutation 27 293-294.

Oberdoerffer P, Kanellopoulou C, Heissmeyer V, Paeper C, Borowski C, Aifantis I, Rao A \& Rajewsky K 2005 Efficiency of RNA interference in the mouse hematopoietic system varies between cell types and developmental stages. Molecular and Cellular Biology 25 3896-3905.

Oka T, Maillet M, Watt AJ, Schwartz RJ, Aronow BJ, Duncan SA \& Molkentin JD 2006 Cardiac-specific deletion of Gata4 reveals its requirement for hypertrophy, compensation, and myocyte viability. Circulation Research 98 837-845.

Okubo A, Miyoshi O, Baba K, Takagi M, Tsukamoto K, Kinoshita A, Yoshiura K, Kishino T, Ohta T, Niikawa N et al. 2004 A novel GATA4 mutation completely segregated with atrial septal defect in a large Japanese family. Journal of Medical Genetics 41 e97.

Pehlivan T, Pober BR, Brueckner M, Garrett S, Slaugh R, Van Rheeden R, Wilson DB, Watson MS \& Hing AV 1999 GATA4 
haploinsufficiency in patients with interstitial deletion of chromosome region 8p23.1 and congenital heart disease. American Journal of Medical Genetics 83 201-206.

$\mathrm{Pu}$ WT, Ishiwata T, Juraszek AL, Ma Q \& Izumo S 2004 GATA4 is a dosage-sensitive regulator of cardiac morphogenesis. Developmental Biology 275 235-244.

Rajagopal SK, Ma Q, Obler D, Shen J, Manichaikul A, Tomita-Mitchell A, Boardman K, Briggs C, Garg V, Srivastava D et al. 2007 Spectrum of heart disease associated with murine and human GATA4 mutation. Journal of Molecular and Cellular Cardiology 43 $677-685$.

Rivera Z, Christian PJ, Marion SL, Brooks HL \& Hoyer PB 2009 Steroidogenic capacity of residual ovarian tissue in 4-vinylcyclohexene diepoxide-treated mice. Biology of Reproduction 80 328-336.

Sarkozy A, Conti E, Neri C, D’Agostino R, Digilio MC, Esposito G, Toscano A, Marino B, Pizzuti A \& Dallapiccola B 2005 Spectrum of atrial septal defects associated with mutations of NKX2.5 and GATA4 transcription factors. Journal of Medical Genetics 42 e16.

Sasaguri H, Mitani T, Anzai M, Kubodera T, Saito Y, Yamada H, Mizusawa H \& Yokota T 2009 Silencing efficiency differs among tissues and endogenous microRNA pathway is preserved in short hairpin RNA transgenic mice. FEBS Letters 583 213-218.

Schluterman MK, Krysiak AE, Kathiriya IS, Abate N, Chandalia M, Srivastava D \& Garg V 2007 Screening and biochemical analysis of GATA4 sequence variations identified in patients with congenital heart disease. American Journal of Medical Genetics. Part A 143 817-823.

Seibler J, Kuter-Luks B, Kern H, Streu S, Plum L, Mauer J, Kuhn R, Bruning JC \& Schwenk F 2005 Single copy shRNA configuration for ubiquitous gene knockdown in mice. Nucleic Acids Research 33 e67.

Seibler J, Kleinridders A, Kuter-Luks B, Niehaves S, Bruning JC \& Schwenk F 2007 Reversible gene knockdown in mice using a tight, inducible shRNA expression system. Nucleic Acids Research 35 e54.

Siltanen S, Anttonen M, Heikkila P, Narita N, Laitinen M, Ritvos O, Wilson DB \& Heikinheimo M 1999 Transcription factor GATA-4 is expressed in pediatric yolk sac tumors. American Journal of Pathology 155 1823-1829.

Sledz CA, Holko M, de Veer MJ, Silverman RH \& Williams BR 2003 Activation of the interferon system by short-interfering RNAs. Nature Cell Biology 5 834-839.

Soudais C, Bielinska M, Heikinheimo M, MacArthur CA, Narita N, Saffitz JE, Simon MC, Leiden JM \& Wilson DB 1995 Targeted mutagenesis of the transcription factor GATA-4 gene in mouse embryonic stem cells disrupts visceral endoderm differentiation in vitro. Development 121 3877-3888.

Szulc J, Wiznerowicz M, Sauvain MO, Trono D \& Aebischer P 2006 A versatile tool for conditional gene expression and knockdown. Nature Methods 3 109-116.
Tang ZH, Xia L, Chang W, Li H, Shen F, Liu JY, Wang Q \& Liu MG 2006 Two novel missense mutations of GATA4 gene in Chinese patients with sporadic congenital heart defects. Zhonghua Yi Xue Yi Chuan Xue Za Zhi 23 134-137.

Tevosian SG, Albrecht KH, Crispino JD, Fujiwara Y, Eicher EM \& Orkin SH 2002 Gonadal differentiation, sex determination and normal Sry expression in mice require direct interaction between transcription partners GATA4 and FOG2. Development 129 $4627-4634$.

Tomita-Mitchell A, Maslen CL, Morris CD, Garg V \& Goldmuntz E 2007 GATA4 sequence variants in patients with congenital heart disease. Journal of Medical Genetics 44 779-783.

Tremblay JJ \& Viger RS 1999 Transcription factor GATA-4 enhances Mullerian inhibiting substance gene transcription through a direct interaction with the nuclear receptor SF-1. Molecular Endocrinolgy 13 $1388-1401$.

Tremblay JJ \& Viger RS 2001 GATA factors differentially activate multiple gonadal promoters through conserved GATA regulatory elements. Endocrinology 142 977-986.

Vaskivuo TE, Aittomaki K, Anttonen M, Ruokonen A, Herva R, Osawa Y, Heikinheimo M, Huhtaniemi I \& Tapanainen JS 2002 Effects of follicle-stimulating hormone (FSH) and human chorionic gonadotropin in individuals with an inactivating mutation of the FSH receptor. Fertility and Sterility 78 108-113.

Viger RS, Mertineit C, Trasler JM \& Nemer M 1998 Transcription factor GATA-4 is expressed in a sexually dimorphic pattern during mouse gonadal development and is a potent activator of the Mullerian inhibiting substance promoter. Development 125 2665-2675.

Viger RS, Guittot SM, Anttonen M, Wilson DB \& Heikinheimo M 2008 Role of the GATA family of transcription factors in endocrine development, function, and disease. Molecular Endocrinolgy 22 781-798.

Wakana K, Akiyama Y, Aso T \& Yuasa Y 2006 Involvement of GATA-4/-5 transcription factors in ovarian carcinogenesis. Cancer Letters 241 281-288.

Wang PY, Koishi K, McGeachie AB, Kimber M, Maclaughlin DT, Donahoe PK \& McLennan IS 2005 Mullerian inhibiting substance acts as a motor neuron survival factor in vitro. PNAS 102 16421-16425.

van de Wetering M, Oving I, Pon Fong MT, Brantjes H, van Leenen D, Holstege FC, Brummelkamp TR, Agami R \& Clevers H 2003 Specific inhibition of gene expression using a stably integrated, inducible small-interfering-RNA vector. EMBO Reports 4 609-615.

Zeisberg EM, Ma Q, Juraszek AL, Moses K, Schwartz RJ, Izumo S \& $\mathrm{Pu}$ WT 2005 Morphogenesis of the right ventricle requires myocardial expression of Gata4. Journal of Clinical Investigations 115 $1522-1531$

Received in final form 6 May 2009

Accepted 1 June 2009

Made available online as an Accepted Preprint 2 June 2009 